\title{
The Wildlife Rescue Programme of the Nam Theun 2 Hydropower Project (Lao PDR)
}

\section{Le programme de sauvetage de la faune sauvage du projet hydroélectrique de Nam Theun 2 (Laos)}

\section{U. Streicher}

Independent Wildlife Management Consultant, Danang City and Senior Veterinarian, Endangered Primate Rescue Center, Cuc Phuong National Park, Vietnam u.streicher@hust.edu.vn

\begin{abstract}
During inundation of the Nam Theun 2 Hydropower Project a wildlife rescue programme was conducted to respond to animal rescue needs. Based on a series of field surveys conducted in 2007 , priority species were identified for rescue and translocation. Once filling of the Nam Theun 2 Reservoir commenced and islands started to form, animals trapped on these islands were captured by various means and translocated to the Nakai - Nam Theun National Protected Area managed by the NT2 Watershed Management and Protection Authority (WMPA) on the north shore of the reservoir. Various data was collected on these animals and a number of these animals were radiotracked after translocation to assess their survival. Such rescue efforts are often considered a mere act of animal welfare or a public relation exercise. The experience of the Nam Theun 2 wildlife rescue programme shows however that a carefully conducted wildlife rescue programme can provide not only invaluable scientific and ecological insights but significantly contribute to conservation of the biodiversity in the area.
\end{abstract}

Key words - wildlife capture, wildlife translocation, wildlife rescue, biodiversity, large-antlered muntjac, conservation

Résumé - Lors de la phase d'inondation du projet hydroélectrique de Nam Theun 2, un programme de sauvetage de la faune sauvage a été conduit. Sur la base d'une série d'enquêtes de terrain réalisées en 2007 , les espèces prioritaires pour un sauvetage et une translocation ont été identifiées. Une fois la mise en eau du réservoir de Nam Theun 2 commencée, les animaux piégés sur les îles récemment formées ont été capturés par divers moyens et relâchés dans la zone protégée « Nakai-Nam Theun National Protected Area » en rive nord du Réservoir. Diverses données ont été collectées sur ces animaux et certains d'entre eux ont été suivis par un système de radiotélémetrie après leur translocation afin d'évaluer leur survie. De tels efforts de sauvetage sont souvent considérés comme un simple acte en faveur du bien-être animal ou comme une opération de communication. L'expérience du programme de sauvetage de la faune sauvage de Nam Theun 2 montre cependant qu'un tel programme 
mené avec soin peut fournir non seulement des informations scientifiques et écologiques inestimables mais peut également contribuer significativement à la protection de la biodiversité dans la région.

Mots-clés - capture de la faune sauvage, translocation de la faune sauvage, biodiversité, muntjac à grand bois, conservation

\section{INTRODUCTION}

Hydropower projects are a main means to respond to the increasing energy needs in the rapidly developing countries of Southeast Asia. Their number is increasing and in many areas they conflict with wildlife conservation requirements as most hydropower projects do not pay specific attention to the wildlife living in the inundation area. The fact that wildlife will perish during inundation is often accepted as a regrettable but overall inevitable side effect. In 1999, Vie provided a review of wildlife translocations conducted on hydroelectric projects, reported on the wildlife translocation conducted at the Petit Saut hydroelectric project in French Guiana, and concluded that such an effort was highly worthwhile and of great scientific interest (Vie, 1999). But still only few hydropower projects have a specific wildlife rescue component.

During the planning of the Nam Theun 2 Hydropower Project conducted by Nam Theun 2 Hydropower Company in Khammouane Province in Lao PDR, one of the environmental requirements was to develop a plan to minimize the damage to wildlife in the project area.

The field surveys conducted in preparation of the Nam Theun 2 Hydropower Project were the first detailed surveys conducted on the
Nakai Plateau and found that the plateau was home to a high diversity of different species. It was clear that during inundation it would be impossible to rescue all animals and large numbers of animals would perish as the water rose. However as long as these animals were representatives of common species and had a large distribution area, their loss would not mean a threat to the species in general and was considered acceptable. But the surveys also found several species on the plateau, which were endemic to a small area within Indochina, occurred only in low numbers or had been significantly reduced in other parts of their distribution range. Their loss would have meant a significant loss to the species.

Based on these considerations a number of priority species were identified for which the rescue of individuals had the potential to significantly enhance the survival of local populations (Tab. I).

The main objective of the wildlife rescue programme was to monitor the reservoir for potential wildlife rescue needs and if necessary, capture and translocate individuals of these species to the adjacent protected area. If they successfully establish there, they could make an important contribution to the local populations of the species in the sense of a re-enforcement as stated by IUCN (IUCN/SSC, 2013). 
Table I. Priority species.

Tableau I. Espèces prioritaires.

\begin{tabular}{|c|c|c|}
\hline English name & Scientific name & $\begin{array}{l}\text { Presence on the Naka } \\
\text { plateau }\end{array}$ \\
\hline \multicolumn{3}{|l|}{ Mammals } \\
\hline Pangolins & Manis spp. & Confirmed \\
\hline Black leaf monkeys & $\begin{array}{l}\text { Trachypithecus laotum } \\
\text { Trachypithecus hatinhensis }\end{array}$ & Unlikely \\
\hline Grey langur & Trachypithecus crepusculus & Unlikely \\
\hline Loris & $\begin{array}{l}\text { Nycticebus pygmaeus } \\
\text { Nycticbus bengalensis }\end{array}$ & Likely \\
\hline Binturong & Arctictis binturong & Probable \\
\hline Lowe's Otter Civet & Cynogale lowei & Unlikely \\
\hline Fishing Cat & Prionailurus viverrinus & Unlikely to probable \\
\hline Jungle Cat & Felis chaus & Probable \\
\hline Leopard & Panthera pardus & Confirmed formerly \\
\hline Tiger & Panthera tigris & Confirmed formerly \\
\hline Asian Black Bear & Ursus thibetanus & Probable \\
\hline Sun Bear & Ursus malayanus & Probable \\
\hline Dhole & Cuon alpinus & Probable \\
\hline Eurasian Otter & Lutra lutra & Probable \\
\hline Hairy-nosed Otter & Lutra sumatrana & Unlikely \\
\hline Oriental Small-clawed Otter & Aonyx cinerea & Confirmed \\
\hline Smooth-coated Otter & Lutrogale perspicillata & Confirmed \\
\hline Eld's Deer & Cervus eldii & Confirmed formerly \\
\hline Hog Deer & Axis porcinus & Probable formerly \\
\hline Large-antlered Muntjac & Muntiacus vuquangensis & Confirmed \\
\hline Banteng & Bos javanicus & Confirmed formerly \\
\hline Gaur & Bos gaurus & Confirmed formerly \\
\hline \multicolumn{3}{|l|}{ Birds } \\
\hline Green Peafowl & Pavo muticus & Confirmed formerly \\
\hline White-winged Duck & Carina scutulata & Confirmed formerly \\
\hline \multicolumn{3}{|l|}{ Reptiles } \\
\hline All tortoises/turtles & Several genera/species & Confirmed \\
\hline
\end{tabular}




IUCN Definitions
"Translocation": deliberate and media-
ted movement of wild individuals or popu-
lations from one part of their range to
another.
"Re-enforcement/Supplementation":
addition of individuals to an existing popu-
lation of Conspecifics

Not all species occurring on the plateau were attended to by the wildlife rescue programme. All turtle species were subject to a programme run by a team from Conservation International $(\mathrm{Cl})$ Cambodia and team from Wildlife Conservation Society (WCS) Laos was responsible to deal with issues concerning the elephant population on the plateau.

\section{MATERIALS AND METHODS}

Preparations to the project started in January 2008 and ended in March 2009. Due to the delay in filling of the reservoir animals were only captured from April 2008 until February 2009.

\subsection{Team composition and training}

The project team leader was a wildlife veterinarian, working in conservation in Indochina since 1997 with experience in capturing wildlife and working in rural areas. She was supported by one to four trained expatriate animal handlers. The project had one project assistant/translator, three boat drivers, three local trackers, one car driver and four tracking dogs.

Staff were intensively trained in the beginning of the project. Staff with veterinary qualification were trained in the performance of anaesthesia in wildlife including drug selection and dosage, anaesthetic monitoring, anaesthetic recovery, emergency measures and the recording of information. All staff received training in use of the rescue gear and specific methods to capture and safely handle different animals. Most of the team was not familiar with the animal species on the plateau and had to be trained in species identification. Staff were furthermore trained in basic animal care principles, including care during transport, temporary housing and husbandry and quarantine principles. Staff also received training in the use of GPS units and navigation, the use of radios and the principles of radio communication. They were thoroughly familiarized with forest conduct, camp site regulations and law enforcement. The most difficult concept to grasp for the villagers was the regulation against removing any wildlife from the Nam Theun 2 Reservoir. Educating staff that proper law enforcement does not allow any exception to this rule was one of the most challenging aspects of training. Several team members participated in first aid training and all team members received rabies vaccinations as a precaution when handling wildlife.

\subsection{Capture equipment}

Capture equipment comprised six iron cage traps in different sizes, of which the largest ones were large enough to trap an adult sun bear. These traps were made on order in Thailand. An additional eight cage traps were obtained from the Conservation International Cambodia Programme. These were standard made collapsible live traps, large enough to 
capture small mammals up to the size of a squirrel or mongoose.

Two catchpoles and two hoop nets, with a hoop diameter of $60 \mathrm{~cm}$ were made on order in Thailand. A dartgun and blowpipes and the necessary darting equipment were ordered from Germany. A field gas anaesthesia kit, pulsoximeter and all major veterinary equipment were provided by the team leader, who preferred to use familiar equipment under demanding circumstances. Heavy duty wildlife handling gloves, blankets, towels and ropes completed the capture equipment.

\subsection{Selection of survey and capture sites}

An area of $489 \mathrm{~km}^{2}$ was supposed to get flooded for the Nam Theun 2 Reservoir. Due to the geomorphology of the plateau it was expected that during inundation a large number of small islands would temporary form on the western part of the plateau in the so called "Thousand Island" area. The majority of these islands would only exist for several days or weeks and then gradually get submerged. Only very few islands were assumed to permanently remain. It was assumed that wildlife would get stranded on islands, where it would find insufficient food sources and be vulnerable to hunting and hence rescue of such stranded animals would be required.

Prior to inundation, surveys on foot were conducted over the entire plateau in all areas, where potentially islands would later form. These surveys were aimed at identifying general animal densities and occurring species. If an area was found to have no priority species and no or only few other wild animals during these surveys, it was excluded from further survey work. Additionally boat surveys were conducted aimed at identifying possible later navigation routes

At water levels from 525 m.a.s.l. to 533 m.a.s.l. a combination of boat and foot surveys was conducted, focusing on the areas east of Ban Thalang (see the map in Descloux et al., same issue), where first islands formed. These surveys provided the baseline data for trapping and rescues in this area.

At water levels from 533 m.a.s.l. to $535 \mathrm{~m}$.a.s.l. islands also formed west of Ban Thalang and were included in the work. Rescues were conducted in all areas where surveys had identified wildlife and on islands small enough that capture appeared feasible.

Once the water reached full supply level at 538 m.a.s.l. most of the islands west of Ban Thalang were very completely isolated and the "Thousand Islands" area was fully accessible and the majority of animal rescues were conducted. At this time, wildlife positive surveys were always immediately followed by rescue efforts.

After the water level reached 535 m.a.s.l. in October 2008, islands had formed over the entire area of the reservoir. Now surveys and rescue efforts were focused on areas where previous surveys had identified high densities of wildlife and possibly priority species.

Once the actual filling started the time spent to survey and rescue wildlife was considerable. Also as wildlife positive surveys were always followed by an immediate capture and rescue effort it was usually impossible to limit 


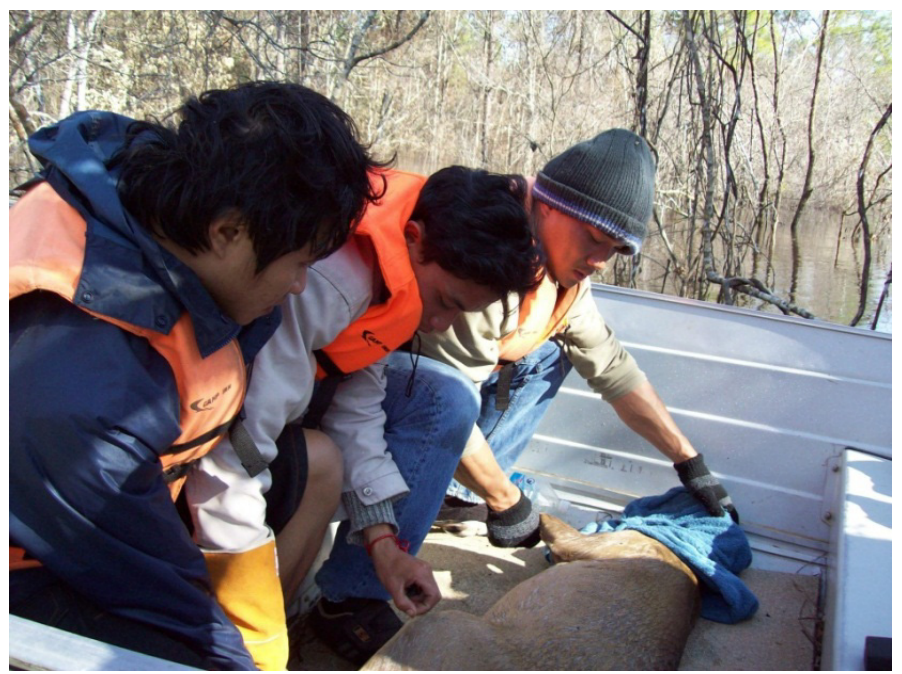

Fig. 1. Capture of a Muntjac.

Fig. 1. Capture d'un Muntjac.

work hours and work was conducted whatever weather conditions. In average surveys were conducted for 358 hours (from $90-460$ hours) per month.

\subsection{Survey and capture methods}

Survey and capture work was usually conducted with three boats with a complete set of survey and capture equipment. The boat carrying the veterinarian additionally carried equipment for field anaesthesia and medical procedures.

Animals were trapped on the island, captured with hoop nets or catch poles or flushed off the islands and captured with hoop nets in the water. Though darting equipment was available the dense vegetation made it impossible to reliably dart on the islands.

For trapping live animals traps were set up on the larger islands and baited with chicken, fish, and various fruit and checked every second day. Traps were moved to a new location about every three weeks, depending on reports and signs of animals on the island, and the frequency of successful trapping. When animals were found in burrows on the islands, they were dug out and captured with hoop nets. Only on two occasions animals were captured with catchpoles.

When ungulates were located on islands, they were captured by strategically placing the boats around the islands and then flushing of the target animal into the water by a driver team with dogs.

Once the animal was successfully flushed off the island and localized, the team in the nearest boat captured the animal with a hoop net; the animal was lifted into the boat and immediately anesthetized (Fig. 1). If an animal could not be flushed into the water within 30 minutes or if the animal escaped to another island and a second capture 


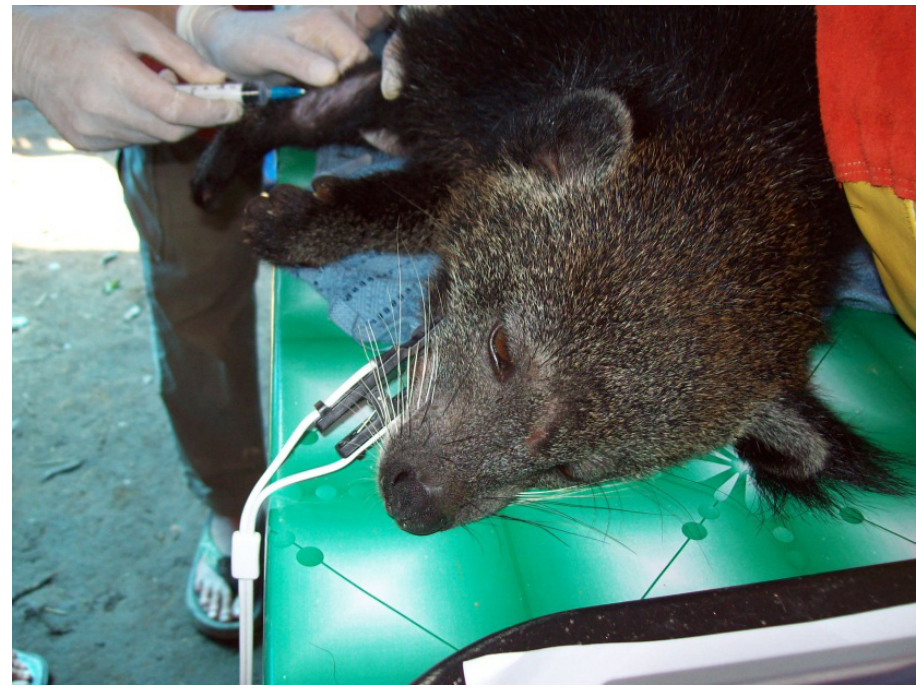

Fig. 2. Health check of a captured Binturong.

Fig. 2. Bilan de santé d'un Binturong capturé.

effort was not successful, the capture of the respective animal was abandoned for that day in order to reduce the risks of exhaustion, capture myopathy and death.

After capture, a thorough health check was conducted on every animal to assess the general health and collect physiological parameters (in anaesthetized animals, Fig. 2). Any injuries were taken care off immediately and data was recorded on an animal capture sheet. Animals were transported to the release site either under anaesthesia, or alert in transport boxes or cages. Specific care was taken to prevent hypothermia or hyperthermia during the transport. Temperature, heart rate, respiration rate and partial oxygen saturation of the blood were checked every ten minutes (Stalder et al., in print).

\subsection{Capture risks and fatalities}

Capture and anaesthesia inevitable holds a health risk for animals. Common health risks associated with wildlife capture are capture myopathy, physical trauma, regurgitation of ruminal fluid or food, bloat, hypothermia/ hyperthermia, shock, respiratory distress, circulatory failure.

To prevent capture myopathy extensive chasing of animals was avoided and captures were abandoned if not successful after 30 minutes. After capture the animals received injections of a Vitamin E Selen combination to prevent acidosis. Application of a short acting tranquillizer (Acepromacin) reduced stress after release and also helped to minimize capture associated problems.

Furthermore, small injuries during tentative of escape of animal were 
immediately and locally treated (cleaned and sometimes long acting antibiotic injection administration) and the animals were released without delay.

Another problem was bloating, as after an hour of transport muntjacs started to visibly bloat, their respiration rate decreased gradually and became shallow. However no interference was required other than speeding up the anaesthetic reversal and release process.

Hyper and hypothermia are a considerable problem for many of the rescues. Some muntjac captures were conducted during months with very high ambient temperatures. Immediately following capture, the animals had a body temperature approaching $40.0^{\circ} \mathrm{C}$ increasing the risk of hyperthermia. Using cold rectal fluids or external cold water applications could reduce the body temperature to around $38.5^{\circ} \mathrm{C}$. Other captures were conducted when low ambient temperatures created the opposite problem. On capture, the animal's body temperature usually was around $38.0^{\circ} \mathrm{C}$, but due to wind chill on the boat, it could rapidly drop to values below $36.0^{\circ} \mathrm{C}$. Rescue foils and full body coverage during transport were necessary to prevent critical hypothermia.

Small animals which appeared weak or cold were kept overnight and were provided with a hot water bottle and additional nesting material. However several squirrels and one Northern treeshrew died due to hypothermia.

Asphyxia (respiratory arrest) occurred during three muntjac captures. The respiration of the animals stopped. In all three cases immediate injection of a respiratory stimulans and immediate anaesthetic reversal resulted in restart of respiration.

Two macaques, one orphaned infant and one young female with a sever snare injury could not be released but where transferred to a facility in Luang Prabang (Lao PDR). One common palm civet and one Northern treeshrew were euthanized. Both animals were found severely injured by hunter traps.

\subsection{Release of wildlife}

\subsubsection{Wildlife requiring holding before release}

Sometimes animals could not be immediately released, because they were injured, weak or sick, wet and in risk of getting hypothermic, dependent young or simply captured too late in the day to allow safe release and return to the operational base in day light. Some species were also included into a wildlife disease study of the Pasteur Institute. In these cases the animals were kept at the small holding facility in Ban Thalang, where appropriate treatment for injuries was applied, the animals were provided with dry nesting material (towels) and hot water bottles. If necessary, animals received fluids, vitamins and minerals. As soon as animals appeared in good condition they were immediately released. The animal holding facility was managed as a quarantine facility and though conditions in the rural environment were of course limited strict quarantine rules applied. 


\subsubsection{Release sites}

The selected release sites were located on the north shore of the Nam Theun 2 Reservoir inside the Nakai Nam Theun National Protected Area. The habitat in this area consists of a patchwork of evergreen drainage forest, dry pine forest and grassland and remained accessible at rising water levels, had a well hidden access, provided maximum security from hunting and was free from presence of domestic animals (buffaloes). Release sites of the Turtle Conservation Programme and several mineral licks of the Elephant Conservation Programme (two additional conservation programmes conducted and funded under the Nam Theun 2 Hydropower Project) were also located in this sector in order to facilitate targeted protection operations by the WMPA and specifically by their Reservoir Patrol Unit which was tasked to work in cooperation with the Wildlife Rescue Program as part of their poaching reduction role. Animals were mostly released in the early afternoon hours. Smaller animals and animals which were not anaesthetized were released further inside the forest, larger animals closer to the edge of the water.

\subsubsection{Release animals}

The IUCN principles for reintroduction apply also to translocation: that means animals to be translocated must exhibit suitable behaviours to be able to survive in the wild and must be free from any sign of disease. In this case there was no change in environmental conditions for the animal and the habitats at the release sites resembled capture habitats and there was no need for a specific adaptation period to a new environment. Animals were only kept for a minimal time and had no contact with animals other than those that were captured simultaneously at the same site. Thus, there were no pre-release quarantine measures taken. Animals were either released on the day of capture or within 48 hours after capture. On release animals had to appear healthy, move normally, be dry and appear not overly stressed.

Prior to release a health check was conducted on every animal. If animals appeared to be in mildly compromised condition, e.g. thin, but not really sick enough to justify keeping them for an extended period of time they received an injection of vitamins and/or fluids and minerals.

All muntjacs received precautionary treatment for capture myopathy and to reduce stress (Vitamin E/Selen, short acting tranquilizer) and were marked with an eartag.

The animals were carried into the forest for a short distance and placed on the forest floor. All mats and blankets were removed. If appropriate, the animal was then given an anaesthetic antidote. All assisting staff retreated from the site, only the veterinarian or animal handler stayed behind to monitor the recovery of the animal.

\subsection{Sampling and data collection}

The aim of the project was the translocation of the animals. There was no specific focus on scientific data collection. However species, capture site, capture time, habitat, capture method, 
estimated weight, general condition, sex, release site and release time were recorded for each animal. When animals had to be sedated after capture data were also collected on anaesthetic drug dosage, time of anaesthesia application, time anaesthetic effect achieved heart rate, respiration rate, temperature, dental condition, estimated age, body measurements and recovery time and of most animals hair sample was taken. All data were stored at Environment and Social Division of the Nam Theun 2 Hydropower Project. Between July and September 2008 blood and swab samples were taken for a wildlife disease study by the Pasteur Institute (Duval et al., in print).

\subsection{Radiocollaring muntjacs}

In preparation of the Wildlife Rescue Programme radio-tracking equipment had been purchased to provide the opportunity for monitoring representatives of priority species after release. According to the original schedule conclusion of the project was supposed to be at the end of September. But by the end of August no priority animals suitable for radiocollaring had been captured and the decision was made to use radiocollars on common muntjacs to assess their survival after translocation. Capture and translocation of ungulates is known to be particularly difficult and even if animals survive the actual translocation, effects of capture myopathy might last for several days or weeks and fatalities amongst translocated animals is usually high. It was hoped to gather some information on the actual survival rates of these sensitive animals.
As the main focus was capture and release of wildlife from the reservoir area, collared animals could only be monitored until the animal moved further into the Nakai - Nam Theun National Protected Area and it became impossible to track them without compromising the capture and release activities.

Later, when large-antlered muntjacs were captured, these were collared as they were priority species of high conservation value. However suitable collars only arrived in late January and were placed on animals in February just before the closure of the project. The actual Wildlife Rescue Programme ended at the end of February but the leader of the Wildlife Rescue Programme returned to the project area in April 2009 to track the large-antlered muntjacs and provide training in tracking methodologies to staff of the National Protected Area.

\subsection{Cooperation with other project components}

During the entire project duration the wildlife rescue programme cooperated very closely with the two other projects charged with wildlife conservation issues. Several times the wildlife rescue teams found turtles on islands or received turtles from villagers. Those animals were handed to the turtle rescue project for further processing. Vice versa the turtle rescue project did not have access to veterinary equipment or skills and if turtles captured within their project required veterinary attention, they were treated by the veterinary staff of the wildlife rescue programme. Once it came to the stage of radiotracking 
translocated wildlife, the wildlife and turtle rescue programmes coordinated transmitter frequencies and equipment use to maximize efficiency of the monitoring efforts. Cooperation with the elephant team mainly consisted in information exchange but occasionally also in direct support of activities eg in one case when a small herd of elephants was found swimming in the reservoir and had to be protected against disturbance.

\section{RESULTS OF THE WILDLIFE RESCUE PROGRAMME}

\subsection{Rescued animals}

A total of 289 animals were rescued during the duration of the project (Tab. II). Of particular importance is the capture of 38 large-antlered muntjacs. All animal rescue locations are shown in Figure 3.

The low number of rescue cases between dam gate closure in April 2008 and June of the same year is accounted for by the delay in reservoir filling (see Fig. 4). The number of rescue events increased immediately after the water level of the reservoir rose (June to November 2008) with a maximum rescue in October 2008. Captures of priority species mainly occurred after the reservoir filling (all priority species and large-antlered muntjacs) from November 2008.

\subsection{Rescue of large-antlered muntjac}

The first large-antlered muntjac female was captured in November
2008. Intensified work in the capture area showed that more large-antlered muntjacs occurred there and required translocation. Given the species' conservation importance, by the end of November 2008 the programme decided to focus primarily on the largeantlered muntjacs (Fig. 4).

Focusing on one species allowed concentrated efforts. Primarily concentrating on muntjacs permitted the wildlife rescue team soon to distinguish between habitats which were likely to hold large-antlered muntjac and other areas which were likely to hold common muntjac and specifically target those areas. Based on the number of signs indicating presence of muntjac on the islands, we estimated that by the end of the programme in February 2009 , about $60 \%$ of the large-antlered muntjac population in the Thousand Islands area had been translocated. The remaining animals had moved to large islands where capture at this time was not possible.

\subsection{Results of the radiotracking of muntjac}

Four common and five large-antlered muntjacs have been equipped with radiocollars during the Wildlife Rescue Programme. Two animals lost the collars shortly after release.

Due to time constraints during Wildlife Rescue Programme the signals initially were only monitored to assess if the animals were alive. The collars used comprised a motion sensor which allowed to detect if the animal was active, inactive or dead. Animals could be tracked from 0 to 30 days after 
Table II. Species rescued.

Tableau II. Espèces sauvées.

\begin{tabular}{|c|c|c|}
\hline Species & Scientific name & Number of individuals \\
\hline Northern treeshrew & Tupaia berlengeri & 16 \\
\hline Sunda colugo & Galeopterus variegatus & 1 \\
\hline \multicolumn{3}{|l|}{ Primates } \\
\hline Pygmy loris & Nycticebus pygmaeus & 13 \\
\hline Northern slow loris & Nycticebus bengalensis & 1 \\
\hline Rhesus macaque & Macaca mulatta & 1 \\
\hline Northern pigtailed macaque & Macaca leonina & 1 \\
\hline \multicolumn{3}{|l|}{ Carnivores } \\
\hline Dhole & Cuon alpinus & 2 \\
\hline Binturong & Arctictis binturong & 1 \\
\hline Common palm civet & Paradoxurus hermaphroditus & 3 \\
\hline Large Indian Civet & Viverra zibetha & 4 \\
\hline Small Asian mongoose & Herpestes javanicus & 2 \\
\hline Crab-eating mongoose & Herpestes urva & 2 \\
\hline Hog badger & Arctonyx collaris & 1 \\
\hline Stripe-backed weasel & Mustela strigidorsa & 1 \\
\hline \multicolumn{3}{|l|}{ Rodents } \\
\hline Black giant Squirrel & Ratufa bicolour & 3 \\
\hline Pallas red-bellied squirrel & Callosciurus erythraeus & 88 \\
\hline Inornate squirrel & Callosciurus inornatus & 7 \\
\hline Red-cheeked squirrel & Dremomys rufigenys & 5 \\
\hline Cambodian striped squirrel & Tamiops rodolphi & 4 \\
\hline Indochinese ground squirrel & Menetes berdmorei & 2 \\
\hline Parti-coloured flying squirrel & Hylopetes alboniger & 3 \\
\hline Hairy-footed flying Squirrel & Belomys pearsoni & 1 \\
\hline East Asian porcupine & Hystrix brachyura & 4 \\
\hline Siames hare & Lepus peguensis & 2 \\
\hline \multicolumn{3}{|l|}{ Ungulates } \\
\hline Sambar deer & Cervus unicolor & 1 \\
\hline Large-antlered muntjac & Megamuntjacus vuquangensis & 38 \\
\hline Common muntjac & Muntjacus muntjacus & 15 \\
\hline Lesser mousedeer & Tragulus javanicus & 7 \\
\hline Wild pig & Sus sp. & 5 \\
\hline
\end{tabular}


Table II. Continued.

Tableau II. suite.

\begin{tabular}{|c|c|c|}
\hline Species & Scientific name & Number of individuals \\
\hline \multicolumn{3}{|l|}{ Other } \\
\hline Sunda pangolin & Manis javanicus & 2 \\
\hline \multicolumn{3}{|l|}{ Reptiles } \\
\hline Water monitor & Varanus salvator & 2 \\
\hline Bengal monitor & Varanus bengalensis & 11 \\
\hline Indochinese waterdragon & Physognathus cocincinus & 1 \\
\hline Elongated tortoise & Indotestudo elongate & 5 \\
\hline Asian leaf turtle & Cyclemys tcheponensis & 2 \\
\hline Indochinese box turale & Cuora galbinifrons & 1 \\
\hline Impressed tortoise & Manouria impressa & 1 \\
\hline Malayan snail eating turtle & Malayemys subtrijuga & 13 \\
\hline Asian giant pond turtle & Heosemys grandis & 1 \\
\hline White lipped pit viper & Trimeresurus albolabris & 1 \\
\hline Burmese python & Python molurus & 2 \\
\hline Indochinese rat snake & Ptyas korros & 2 \\
\hline Common rat snake & Ptyas mucosus & 1 \\
\hline \multicolumn{3}{|l|}{ Birds } \\
\hline Siamese fireback & Lophura diardi & 1 \\
\hline Red junglefowl & Gallus gallus & 1 \\
\hline White headed laughing thrush & Garrulax leucolophus & 3 \\
\hline Chinese pond heron & Spizaetus nipalensis & 1 \\
\hline Chinese francolin & Francolinus pintadeanus & 2 \\
\hline Mountain hawk eagle & Spizaetus nipalensis & 1 \\
\hline Mandarin duck & Aix galericulata & 1 \\
\hline
\end{tabular}

release and in average, they were tracked for 9 days after release. This allows to say that no animal died immediately after release and $66 \%$ of the translocated and collared muntjacs definitely survived the first week after release. None of the collared animals was found dead in the vicinity of the release site during the whole duration of the project. Considering the well documented high fatality rates amongst captured ungulates this is considered a very positive result.

During the tracking survey conducted in April 2009, more than two months after the end of the Wildlife Rescue Programme, we were able to locate a female and male large-antlered muntjac northeast of the release site (Fig. 5). Despite the shortage of the 


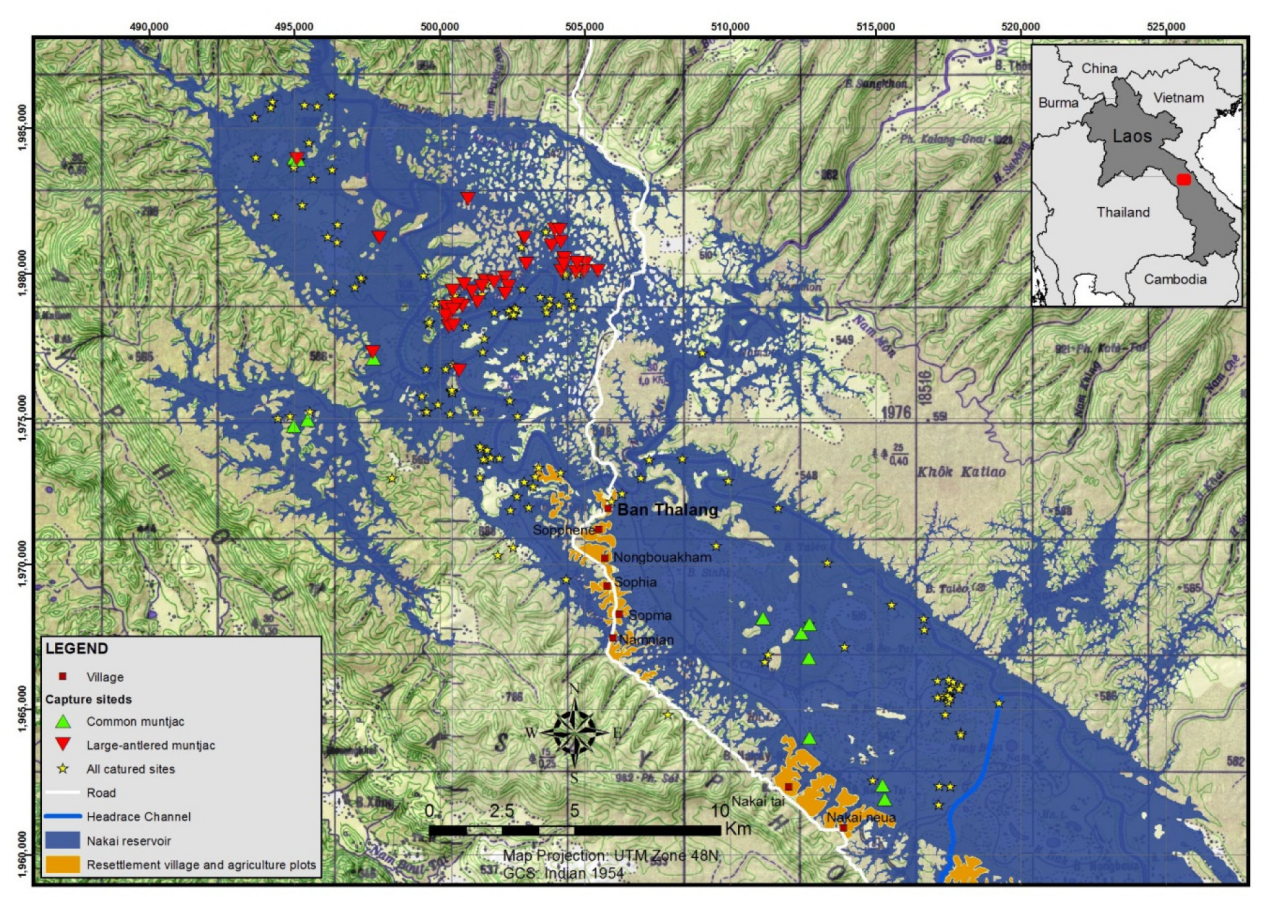

Fig. 3. Capture sites.

Fig. 3. Sites de captures.

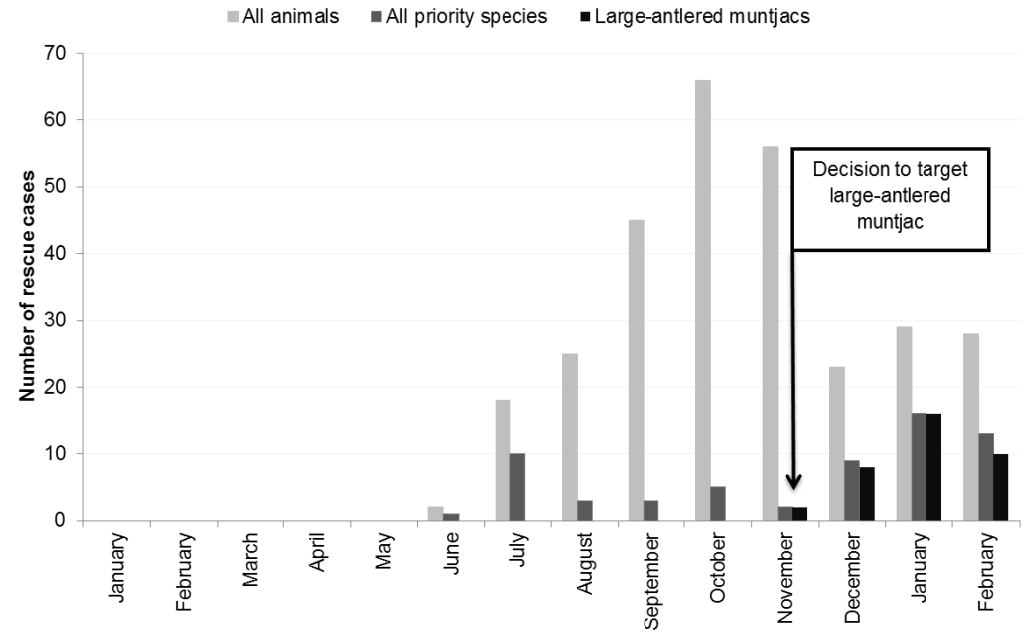

Fig. 4. Rescue frequency over the year of the programme (start of impoundment: April 2008).

Fig. 4. Fréquence de sauvetage sur l'année du programme (début de la mise en eau : avril 2008). 


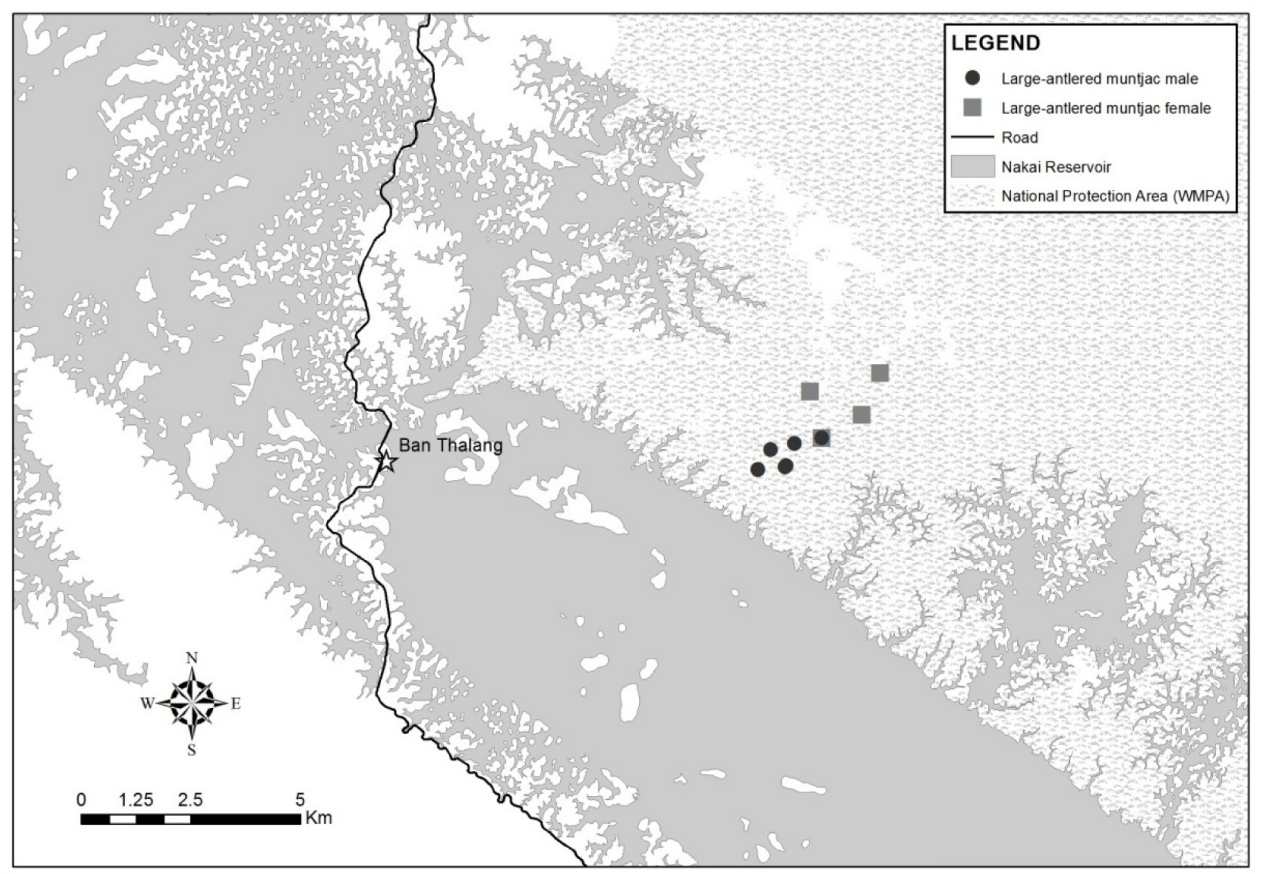

Fig. 5. Tracking locations where signal from large-antlered muntjac male and female were received. Fig. 5. Localisation des signaux reçus des Muntjacs à grands bois mâles et femelles.

time of the surveys, it was possible to assess that the animals were active and moved with some regularity in the area, which could indicate that the animals have established a stable homerange in this area.

\subsection{Considerations on rescue and translocation of conservation relevant species}

Pictures of relevant species are presented in Appendix 1.

Pygmy loris Nycticebus pygmaeus

Little is known on distribution and ecology of the small nocturnal primate (Appendix 1, Photo 1). But reports from Cambodia and Vietnam indicate that the species is rapidly declining in most of its distribution range. It was also regularly found in markets surrounding the project area. However, during night survey work on the reservoir a number of lorises were rescued. Night surveys could only be conducted in a restricted area and only for a limited time, but this suggests that lorises were still abundant on the Nakai plateau at project inception. The night surveys also confirmed observations from Duckworth (1994), who found the species to be directly sympatric, an observation that has not been made in any of the other countries where lorises occur.

Binturong Arctictis binturong

The binturong has a large distribution area within Southeast Asia and in 
some areas still remains widespread (Fig. 2). The capture of the animal on the Nakai Plateau however means a significant extension of the species' range in Lao PDR. The translocation of a single young adult male has potentially a positive impact on the resident breeding population.

\section{Small Asian mongoose Herpestes} $s p$.

Two small Asian mongooses have been captured during the course of the project (Appendix 1, Photo 2). There is evidence that the Small Asian mongoose on the Nakai Plateau differ from Small Asian mongooses elsewhere in Lao PDR and the region. Unfortunately this information was not available to the wildlife rescue teams during the course of the project thus minimal data was collected as the animal was categorized as a non-priority species. Several photographs are however available. A pair of small Asian mongooses were spotted around the release site several weeks after the release. This indicates that the species is present at the release site and it is likely the released individuals had an opportunity to integrate into the existing population.

Colugo Galeopterus variegatus

The unexpected capture of a Colugo was one of the big surprises in the Wildlife Rescue Programme and was only the second field observation of a colugo in Lao PDR (Appendix 1, Photo 3). Data collected on this animal helped to provide a better understanding of this enigmatic species (Stalder et al., 2009). Colugo numbers in the wild are low and the successful translocation of even a single individual can be an important contribution to the species' survival.
Hairy-footed flying squirrel Belomys pearsoni

Parti-coloured flying squirrel Hylopetes alboniger

Little is known about the small flying squirrels (Appendix 1, Photo 4) and the rescues during the project provided only the fifth record for this species in Lao PDR. It also showed that at least two small flying squirrel inhabit the plateau, a fact previously unknown. The capture of these animals in daylight was a surprise well as their agility and confidence moving between trees in daylight given their nocturnal activity pattern. This species occurs in very low numbers and in this case every translocated individual can be a valuable contribution to the species' conservation.

Stripe-backed weasel Mustela strigidorsa

The Stripe-backed weasel is one of the least known small carnivores in the world (Appendix 1, Photo 5). The species has not been recorded in the 2007 baseline surveys for this project. Our record not only first confirmed this species on the plateau but also provided the first full set of photographs and measurements of a live specimen (Streicher et al., 2010).

\section{Sambar Cervus unicolor}

Villagers captured a young Sambar swimming in the reservoir, which was taken over by the wildlife rescue team and released. Evidence of Sambar deer (Appendix 1, Photo 6) was found in a few locations east of Ban Thalang prior to inundation. It appeared the Sambar on the plateau has large home ranges, therefore the general density of these animals is very low.

Large-antlered muntjac Megamuntjacus vuquangensis 
This species was only described in 1994 and is the largest of the muntjac species with males reaching weights of up to about $60 \mathrm{~kg}$ (Appendix 1, Photo 7). It is endemic to the Annamite mountain range in central Vietnam and Lao PDR. Very little is known about this species ecology. Though the presence of these animals in the reservoir area was known, nothing was known about the species' density on the plateau, its distribution pattern on the plateau, its ecology or even its morphology. Furthermore muntjacs are possibly the most hunted wildlife species on the plateau and are hunted not for the trade but for direct consumption. Signs of muntjac hunting and hunting parties searching for muntjacs were frequently found on the plateau. The capture and translocation of these animals was of high conservation value for two reasons: firstly once muntjacs were isolated on an island there was no chance that these animals could survive the hunting pressure for long especially on islands that were easily accessible. Furthermore the existing populations of large-antlered muntjacs in the Nakai - Nam Theun National Protected Area are likely to be depleted due to high hunting pressure and the addition of 38 healthy breeding animals to a depleted population means a significant contribution to the species' conservation.

\section{Dhole Cuon alpinus}

Two dhole cubs were found by hunters on the plateau and transferred to the rescue programme. The animals were in very bad condition and died after only a few days despite all efforts. Although this is a sad loss, reintroducing captive reared carnivores is a longterm project that is beyond the capacity of the Wildlife Rescue Programme and requires adequate facilities, as the animals would have had to remain in a captive facility for the rest of their life and such a facility does at present not exist in Lao PDR. For the wild dhole populations, these cubs were lost regardless. However their finding confirms the occurrence of dhole on the plateau, a fact not confirmed prior to this programme.

Sunda pangolin Manis javanica

Little known and heavily exploited, both pangolin species are meanwhile amongst the highly prized items in the wildlife trade. Knowledge on their ecology is still rudimentary, the species suffers from hunting and wildlife trade, and its future is unsure. Pangolins (Appendix 1, Photo 8) were confiscated by the Reservoir Protection Unit of the Watershed Management Protection Authority of Nakai Nam-Theun from hunters. They were not meant for immediate consumption but for the trade. This highlights the effectiveness of wildlife trade networks in the region. Obviously even in a remote area like Ban Thalang a hunter has no problem to find a trader for pangolins.

Efforts to reintroduce trade confiscated pangolins often fail. The chance of survival of reintroduced pangolins depends on the time they have spent in captivity and transport prior to release; the shorter the time the higher the probability of survival. As these animals were intercepted directly from the hunter and only spent a few days in captivity they should have a chance of survival and possibly be able to contribute to the wild population. 


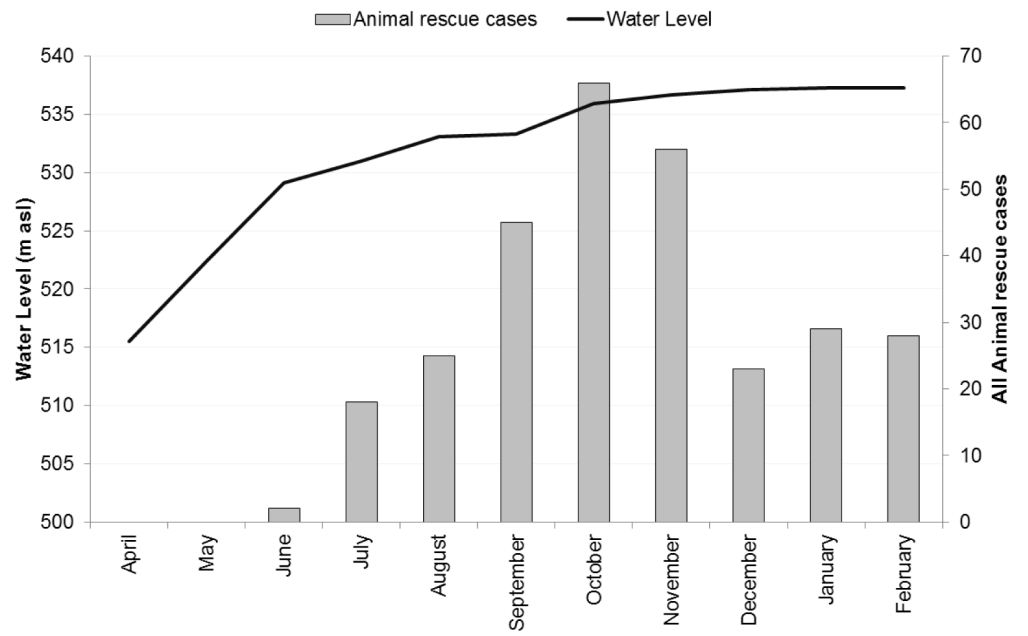

Fig. 6. Rescue frequency and filling of the reservoir (asl = above sea level).

Fig. 6. Fréquence de sauvetage et mise en eau du réservoir (asl = au-dessus du niveau de la mer).

\section{DISCUSSION}

Wildlife rescue and translocation was the main purpose of the programme. A total of 289 animals were translocated. The low number of rescue cases is a result of the extremely slow filling regime. Animals on the Nakai Plateau experienced flooding regularly and were familiar with the need to withdraw to higher grounds on the North of the Plateau. Many animals apparently moved out of the inundation, when major parts of their homeranges were flooded. The results of the programme suggest that only animals with small homeranges remained on the islands and required translocation. During the entire project the expected large scale drowning of animals was never observed. The only animal except of fish, which was found dead in the reservoir was one domestic goat near Ban Thalang. However we did observe very large water monitors and pythons and we assume that the healthy numbers of these excellently swimming predators might have kept the reservoir free of carcasses.

The extremely low number of fatalities during the wildlife capture and translocation has to be accounted to the careful and deliberate implementation and has to be considered an outstanding success. Many representatives of species with a high conservation value were translocated and can make a potential contribution to local populations of those species.

But appropriate timing of activities is essential to stake financial resources and manpower economically. $93 \%$ of all rescue cases occurred only after August 2008, when the water level rose above 533 m.a.s.l. (Fig. 6). 47\% of all rescue cases occurred after November 2008, when the water level rose above 535.90 m.a.s.l. Only when islands 
became small could be effectively localized and rescued.

After setting up the logistical framework for the programme, implementation of the capture phase of the programme should only be started after continuous surveys show that conditions are favourable for captures (size and accessibility of islands, presence of animals on islands). But the occurrence of stranded wildlife is very much subject to the filling regime and the geomorphology and beyond the control of the wildlife rescue team. Though a large number of animals have been rescued and translocated during the course of the project, a number of individuals remained after project closure on large island in the Thousand Island area. But at that time the project had already been extended twice and funds and staff were exhausted. Later commencing of the programme would have allowed to continue after the complete filling of the reservoir. In any case planning of such a programme should in the future always extend for several months after the reservoir reaches full level.

It is scientifically extremely valuable to conduct a wildlife rescue programme during the inundation of a large natural habitat. Every site has its unique geomorphological features and the behaviour of wildlife can simply not be predicted. Such rescue programme might lead to the discovery of new species for the area or the country, which are not detected in previous baseline surveys. Stranded and rescued wildlife provides a unique possibility for data collection on animals. During the Nam Theun 2 Hydropower Project the Wildlife Rescue Programme was able to gather information of substantial scientific value. Inundation provided unique possibilities to gather, which could not be gained in traditional surveys and the translocation and direct handling of the animals gave the opportunity to collect comprehensive data. The unique accessibility of forest at canopy level during inundation is a huge opportunity for scientists and should be maximally utilized also with botanical studies. However no scientific work was conducted after the end of the Wildlife Rescue Programme and the huge opportunity to keep radiotracking the radiocollared large-antlered muntjacs after April 2009 was missed. And only continuous research in the reservoir area and the neighbouring protected areas does finally allow to assess the true impacts of the inundation project to local biodiversity.

The increase in water levels and the change in the environment made the animals vulnerable to hunting. The more habitat disappeared the more animals got displaced from their home ranges. The islands got easily accessible and hunting pressure increased in areas which before were very difficult to access. Protection of capture sites and release sites as well as a very close cooperation of the wildlife rescue team with the forest protection authorities was vital during the project. Cooperation with forest protection authorities must be very close at all stages of the programme from the initial stages onward and forest protection forces should actively participate in capture and translocate whenever possible to ascertain capacity building in animal handling which is a vital skill for forest protection rangers. Forest protection 
rangers should be trained and equipped so after project closure they have the ability to respond to further wildlife rescue needs should those occur.

In respect to achieve sustainable conservation of wildlife on the Nakai Plateau, raising awareness was an important output of the Wildlife Rescue Programme. The placement of the project staff in a resettlement village ascertained a very close relationship with the local population and daily possibilities for awareness raising. In fact, several wild animals were brought to the Wildlife Rescue Programme by villagers. These were animals with a high consumption value (sambar, monitor) or a high trade value (tortoises). The programme was not able to give any kind of financial incentive to local people handing over wildlife and there was no benefit for local people to do so. The animals were given to the project in a genuine effort to contribute to wildlife rescue and not for material benefits.

Another shortcoming was that within the programme there was no option for a reward or pay raise if exceptionally hard work was required. Basing the programme at the resettlement village ascertained that local people did clearly understand and support the purpose of wildlife rescue and translocation and conservation of wildlife on the plateau

\section{CONCLUSION}

To implement a wildlife rescue and translocation programme is an important and worthwhile measure to minimize the negative impacts of a hydropower project to the local biodiversity. It does not only rescue individuals of species of conservation value and allow that these can still contribute to the population of the species. It also allows continuous monitoring of the wildlife situation on the newly forming reservoir and is an important means to recognize and prevent illegal activities. It holds immense scientific possibilities and is a very important means to create awareness in the local population. The benefits by far outweigh the relatively low cost and this opportunity should not be missed in any hydropower project.

\section{ACKNOWLEDGEMENTS}

Conducting this programme was a challenge by some considered impossible, therefor I firstly want to thank Klaus Schoenfeldt and Stuart Gillon from the Nam Theun 2 Hydropower Company for charging me with this task. Against all odds and those were many they never seized to believe that I could run this. I know that they never regretted their choice of consultant. After Klaus left Stephen Duthy continued to provide the same kind of support. They demonstrated how important it is to delegate and have confidence in others. Many thanks to all of them, wherever they meanwhile are. Many thanks to all foreign assistants, Brian Crudge, Gabrielle Stalder, Sebastian Ball, Neville Broadis and Ahmad Mas' Adi. Thanks to my incredible Lao team - Lamphoune, Hongkham, Tuksamphane, Boee, Viet, Top, Joy and my Thalang staff Vanna, Somda, Mei, Khenkham, Chan and Son. And thanks to my working dogs, Ma Dam, Ma Deng, Ma Cao - without 
them we would have achieved much less. Thanks to the people of Thalang, who made us feel at home there and celebrated every success with us how ever strange our work must have appeared to them. Thanks to the WMPA staff for excellent cooperation. Thanks to Will Duckworth and Bill Robichaud for remaining interested in the scientific findings of our programme all the way long.

\section{REFERENCES}

Descloux S., Guédant P., Phommachanh D. \& Luthi R. Main features of the Nam Theun 2 hydroelectric project (Lao PDR) and the associated environmental monitoring programme. Hydroécol. Appl. 19 (same issue).

Duckworth J.W., 1994. Field sightings of the pygmy loris Nycticebus pygmaeus in Laos. Folia Primatol. 63 : 99-101.

Duval L., Streicher U., Stalder G., PourrutX., Bourgarel M., Ebang Ella G., Leroy E., Landau I., Brey P. \& Ariey F. New molecular data on two Haemosporidia rodent parasites: Plasmodium atheruri from African brush-tailed porcupines and Hepatocystis $s p$. from Asian squirrels. Parasitol. Research, in print.

IUCN/SSC, 2013. Guidelines for Reintroductions and Other Conservation Translocations. Version 1.0. Gland, Switzerland: IUCN Species Survival Commission, viiii $+57 \mathrm{p}$.

Stalder G., Broadis N., Mas' Adi A. \& Streicher U., 2009. Field Observation, Capture and Anaesthesia of a flying lemur (Galeopterus variegates) in Lao PDR. Der Zoologische Garten 79 (2-3) : 105-108.

Stalder G., Heymerle A. \& Streicher U. Capture and Anaesthesia of Large-antlered Muntjac (Megamuntjcus vuquangensis) under extremely stressful conditions, in print.

Streicher U., Duckworth J.W. \& RobichaudW., 2010. Further records of Stripe-backed Weasel Mustela strigidorsa from Lao PDR. Tropical Natural History 10 (2).

Vie J.-C. 1999. Wildlife Rescues - the case of the Petit Saut hydroelectric dam in French Guiana. Oryx 33 (2) : 115-126. 


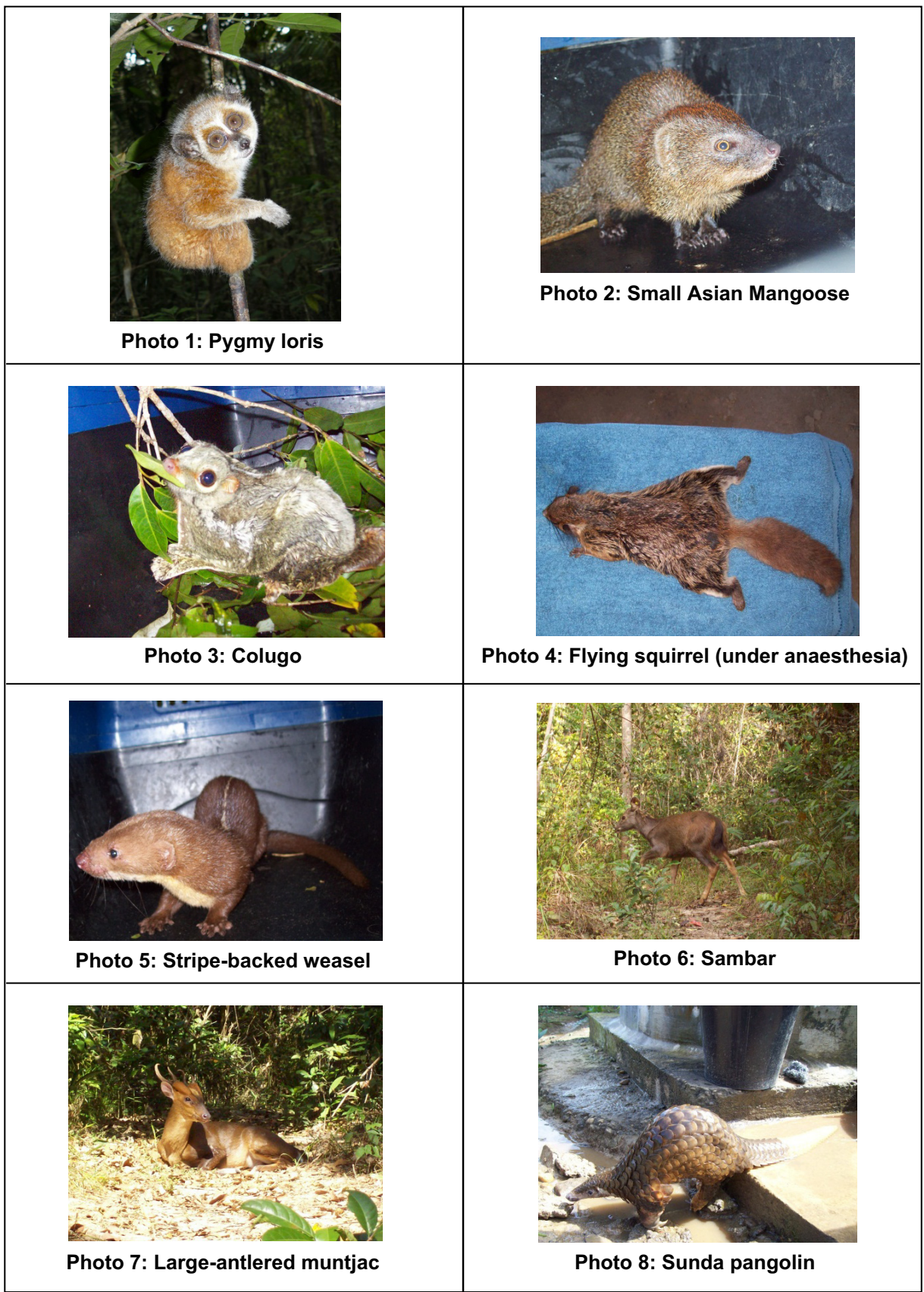

Appendix 1. Pictures of some relevant species from the wildlife rescue and found in the NT2. Annexe 1. Photo de quelques espèces concernées par le sauvetage de la faune sauvage et trouvées au niveau de NT2. 